\title{
The effect of cultural dimensions on tourism promotion in Jordan
}

\author{
Faraj Harahsheh $^{\mathbf{a}^{*}}$
}

${ }^{a}$ Department of Business Administration, Faculty of Administration, Al-Israa University, Amman, Jordan

\begin{tabular}{l}
\hline C H R O N I C L E \\
\hline Article history: \\
Received: September 5, 2018 \\
Received in revised format: Octo- \\
ber 8,2018 \\
Accepted: November 1, 2018 \\
Available online: \\
November 1, 2018 \\
\hline Keywords: \\
Cultural dimension \\
Tourism promotion \\
Tourism directorates
\end{tabular}

\section{Introduction}

The interest in tourism sector began after the Second World War, the tourism sector grew and developed significantly and it was able to achieve a great growth more than other economic sectors, especially in non-oil countries (Cole, 2006). According to the World Tourism Organization (WTO), the most beneficiaries countries of the tourism sector are developing countries.(UNWTO, 2018). The tourism sector at the end of twentieth century, and at the beginning of twenty-first century has great remarkable development, It was called the golden age of tourism, the most important factors that helped the development of tourism are the role of media to introduce the tourism areas, and the cultural awareness of the communities about the importance of tourism, the legislation and laws, that contributed to the development of the tourism sector, and the availability of various tourist facilities such as hotels, restrooms, transportation, and travel offices. According to W.T.O. (2018), tourism has become a socio-economic phenomenon and needs attention and occupies important subject in the economic activities of some countries. The international tourist arrivals grew by $7 \%$ in 2017 to 1,323 million and International tourism generated US\$ 1.6 trillion in export earnings in 2017. UNWTO forecasts a growth in international tourist arrivals of 4-

* Corresponding author.

E-mail address: faraj_harahsheh@yahoo.com (F. Harahsheh)

(C) 2019 by the authors; licensee Growing Science, Canada doi: $10.5267 /$ j.msl.2018.11.001 
5\% 2030. UNWTO also forecasts international tourist arrivals to reach 1.8 billion in 2030 (UNWTO, 2018). The number of tourists in Jordan in 2017 was of about four million and the tourism revenues reached 4.2 billion dollars. Moreover Jordan came number sixth in terms of the number of tourists in Arab countries. It has a variety of tourist attractions, such as cultural tourism, Religious tourism, Medical tourism, Scientific Tourism, Conference tourism, Sport tourism, etc. (Ministry of Tourism, Jordan, 2018). The Jordanian society culture, represented by customs, traditions, values, norms and religious beliefs, plays a major role in tourism promotion. Tourism is not just an entertainment, but also it is an economic industry; countries spend millions of dollars in investment on tourism, because it has become an important economic and social option, it is important that the community has a tourism culture, and tourism awareness that contributes to the success of tourism promotion and development, tourism culture in some Arab societies remains cautious about tourism concept and the negative images created form some other societies about tourism. Tourism promotion is important in tourism marketing, it works to achieve tourism awareness, stimulate demand for tourism content, spreading tourism knowledge to community, and work to achieve tourist's satisfaction with tourist product.

\section{Research Methodology}

\subsection{Aims of the study}

The aim of the study is to identify the role of cultural dimensions of Jordanian society; namely customs $\&$ traditions, values, norms and religious beliefs and their relationships with tourism promotion in Jordan in terms of the managers working in tourism directorates in Jordan.

\subsection{Problem and questions of the study}

Society culture which includes customs \& traditions, values, Norms, religious beliefs plays an important role in promoting and attracting tourists. Jordan is a tourism country and has different characteristics, which makes it a tourist destination. Jordan has a conservative society and a lot of undesirable meanings in Jordanian society culture, such as behavior patterns, dress, and appearance, especially foreign tourists, community participation play an important role in tourism process and tourism promotion. Thus, the problem is to learn about the weakness and the lack of awareness among some communities about the role of Jordanian society culture in tourism promotion in Jordan. The problem of the study is represented in answering the following question:

1. What are the roles of cultural dimensions of Jordanian society including customs \& traditions, values, norms and religious beliefs and their relationships with tourism promotion in Jordan?

2. What is the role of customs and traditions of community and their relationships in tourism promotion in Jordan?

3. What is the role of values of community and its relationship in tourism promotion in Jordan?

4. What is the role of norms of community and its relationship in tourism promotion in Jordan?

5. What is the role of beliefs of community and its relationship in tourism promotion in Jordan?

Fig. 1 shows the structure of the proposed study.
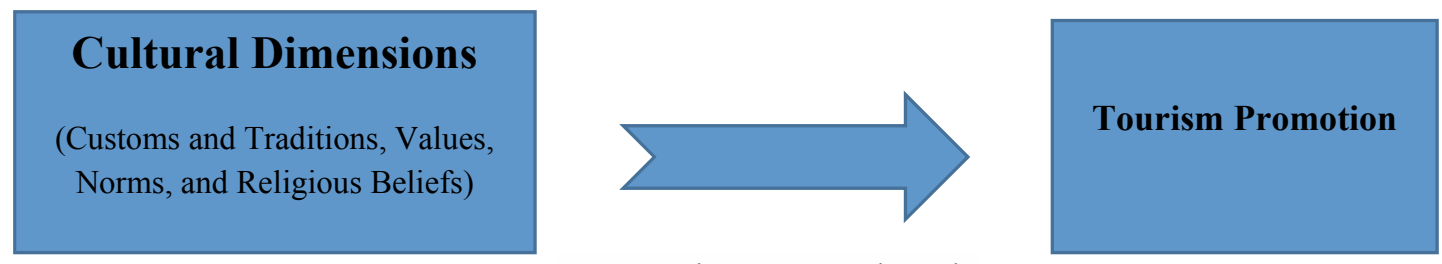

Fig. 1. The proposed study

The subject is important because in the Jordanian economy; the tourism contributed about $14.2 \%$ to national income in 2017 and it plays an essential role in creating direct and indirect jobs for the community. 


\subsection{Study Hypotheses}

The study relied on a set of assumptions, which aimed mainly to understand the role of Jordanian cultural society dimensions represented by customs \& traditions, values, norms, and religious beliefs, and its relationship in of the tourism promotion in Jordan. The hypotheses were formulated as follows:

The main hypothesis: There is no statistically significant positive relationship between society cultural dimensions and tourism promotion in Jordan. The main hypothesis is represented by the following hypotheses:

1. HO: There is no statistically significant positive relationship of customs and traditions in tourism promotion in Jordan.

H1: There is statistically significant positive relationship of customs and traditions in tourism promotion in Jordan.

2. HO: There is no statistically significant positive relationship of values in tourism promotion in Jordan. H1: There is statistically significant positive relationship of values in tourism promotion in Jordan.

3. HO: There is no statistically significant positive relationship of norms in tourism promotion in Jordan. H1: There is statistically significant positive relationship of norms in tourism promotion in Jordan.

4. HO: There is no statistically significant positive relationship of religious beliefs in tourism promotion in Jordan.

H1: There is statistically significant positive relationship of religious beliefs in tourism promotion in Jordan.

\subsection{Method of the Study}

The study population consists of all the managers, assistant mangers, and heads of the departments as well as the directorates of tourism in Jordan, in the North, Central and South Region in Jordan. The study distributed 66 questionnaires among them and 60 questionnaires were collected, two (2) were found not valid for analysis, thus, 58 were valid for analyses. Descriptive statistics (frequency, percentages) were used to analyze the data using the Statistical Package for the Social Sciences (SPSS)

\section{Theoretical Framework}

\subsection{Previous Studies}

Simpson (2001) investigated the role of stakeholder driven strategic planning as a contributor to the ultimate sustainability of tourism development. Ying and Zhou (2007) compared the experiences of tourism development in two of China's most famous rural cultural tourism destinations and reported that despite the fact there were some similarities in tourism settings between these two adjacent destinations, significant changes were detected in their outcomes of tourism developments. According to Goodwin (2002), National Parks maintains tourist attractions located in relatively remote and marginalized rural areas. Goodwin (2002) in an empirical investigation explored the opportunities for local economic development through tourism at different Asian regions. According to Simpson (2008), Tourism is portrayed as "a destroyer of culture, undermining social norms and economies, degrading social structures, stripping communities of individuality; and as a savior of the poor and disadvantaged, providing opportunities and economic benefits, promoting social exchange and enhancing livelihoods". Blackstock (2005) criticized tourism industry for the same reasons discussed by Simpson (2008). Blake (2018) discussed some reflections on community involvement in safeguarding intangible cultural heritage. Dragouni and Fouseki (2018) shed light on the drivers of community participation in heritage tourism planning.

\subsection{Cultural Dimensions and Tourism Promotion}

\subsubsection{Society Culture}

Society culture is the information systems which are common in society and consists of different elements such as customs \& traditions, religion, norms, and binding for society members, etc. Culture exists 
where humans exist, society is defined as the organized group of people sharing the same geographical territory or social territory. In addition, the term culture is represented by the knowledge, belief, art, morals, law, custom and habits, language, norms acquired by people as a member of society.

\subsubsection{Dimensions of society culture}

The culture of people stems from sources that have been created, and the culture of any society is a set of components and references. Culture was defined as the symbols, language, values, beliefs, and language that define a society.

There are several elements and dimensions for culture:

1. Symbols: every culture is filled with symbols, or things that stand for something else, and often evoke various reactions and emotions. Some symbols are actually types of nonverbal communication, while others are in fact material objects.

2. Language: The group of characters and symbols that the members of the community can communicate with each other and transfer everything related to them for future generations.

3. Norms: set of provisions and controls that a society is familiar with has become a law that they are fully committed to in order to be of assistance to the law in the prevention of crime and deviation.

4. Rituals: different cultures also have different rituals, or established procedures and ceremonies that often mark transitions in the life course. As such, rituals both reflect and transmit a culture's norms and other elements from one generation to the next.

5. Values: values are important element of culture and involve judgments of what is good or bad and desirable or undesirable.

6. Artifacts: it is a material objects that constitute a society's material culture. Artifacts are largely limited to a few tools, the huts people live in, and the clothing they wear.

7. Customs and traditions: are the style of a nation or people in social life and its laws.

8. Religious beliefs: is the entire collection of beliefs, values, and practices that a group holds to be the true and sacred, religious beliefs explain where the people fit in relation to the universe and how they should behave while here on earth.

\subsubsection{Concept of tourism promotion}

The promotion of tourism services is one of the most important elements of service marketing mixes. It creates knowledge of customers about the tourism companies, various programs, working to provide a positive interaction between the customer and the tourism organization through the information obtained from the promotional efforts. The promotion of tourism services plays an important role in informing the organization, and enhancing its relationship with its target audience and plays an active role in increasing the customer loyalty to the services of the organization and influencing the purchasing behavior. There are several definitions for promotion (McCarthy \& Perreault, 1993) (the process of contacting potential clients, (Belch \& Belch, 2004) defined tourism promotion as "coordinating the organization's efforts related to building channels of information and desirable levels of persuasion for the purpose of selling the product". It is clear that promotion is a set of means used by organizations to communicate with current and potential customers. The goal of this communication is to create the knowledge for the customers about organization, tourism programs and then influence their purchasing decisions and orient them towards the services of a particular tourist organization.

\subsubsection{Promotion Elements}

According to Dibb and Simkin (1997), the elements of the promotional mix are advertising, personal selling, sales promotion, propaganda and public relations. According to Kotler et al. (2000), the promotional mix elements are advertising, direct marketing, sales promotion, personal selling, propaganda and public relations. 


\section{The Statistical Analysis}

The role of cultural dimensions of Jordanian society and their relationships with tourism promotion in Jordan was examined through statistical analysis of the existing information set, which was summarized in a questionnaire and distributed to a group of directors and heads of departments in the directorates of tourism in Jordan for their opinions using the Statistical Package for the Social Sciences (SPSS). The reliability of the data was measured based on Cronbach's Alpha which was calculated as 0.8278 based on 22 sample data. Fig. 2 demonstrates personal characteristics of the participants.

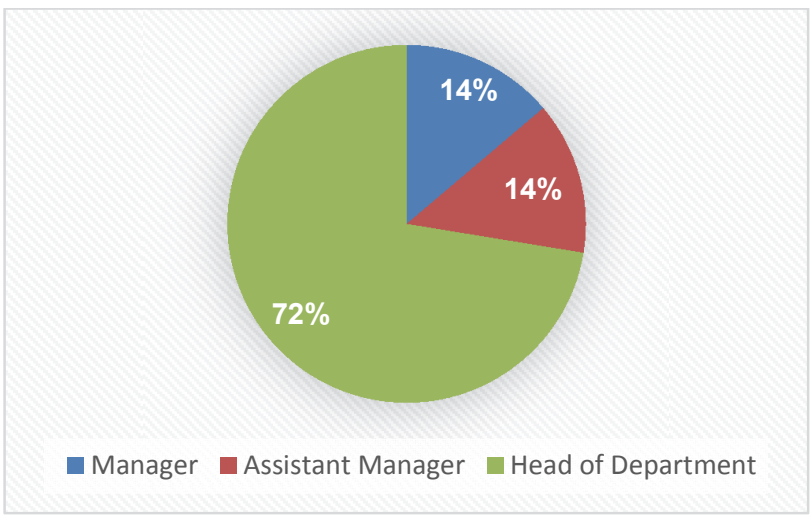

Position

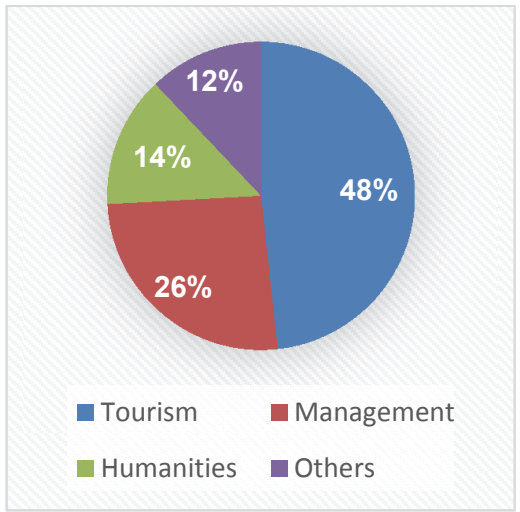

Specialties

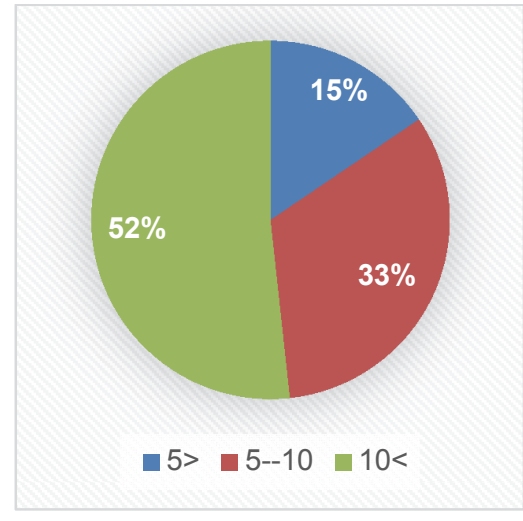

Years of experience

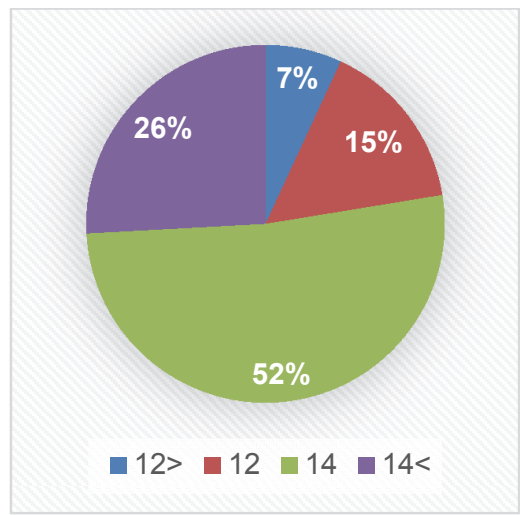

Years of education

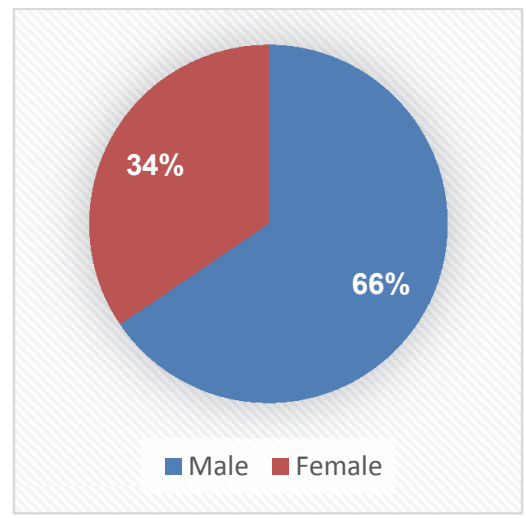

Gender

Fig. 2. Personal characteristics of the participants

These paragraphs were responded to by the five-dimensional Likert Scale, Where it starts at grade (strongly agree) and is given (5) degrees, then (agree), and is given (4) degrees, then (undecided) which is given (3) degrees, then (disagree) and is given (2) degrees, and finally, with (strongly disagree) and is given only (1) degree. The researcher adopted a positive or negative indicator of the degree as follows: The maximum limit for the alternatives of the study instrument is 5, and the minimum of the alternatives is 1 , and by subtracting the minimum limit from the upper limit the score would be (4) degrees, and then dividing the difference between the two levels on three levels as shown in the following equation: 4/3levels (high, medium, low) $=1.33$ and so:

1. Minimum limit $($ low $)=1+1.33=2.33$

2. Average limit (medium) $=2.34+1.33=3.67$

3. Upper limit (high) $=3.68$ and above

Thus, the weights of (3.68- 5.0) are considered high, (2.34-3.67) are assumed medium, and finally (1.002.33) are given low priorities. 
Table 1

The summary of means and standard deviations of elements of cultural dimensions

\begin{tabular}{|c|c|c|c|c|c|}
\hline Rank & $\begin{array}{c}\text { Paragraph } \\
\text { Number }\end{array}$ & Paragraph & $\begin{array}{l}\text { Arithmetical } \\
\text { Mean }\end{array}$ & $\begin{array}{l}\text { Standard } \\
\text { Deviation }\end{array}$ & $\begin{array}{r}\text { Degree of } \\
\text { assessment }\end{array}$ \\
\hline \multicolumn{6}{|c|}{ Sub-Field: Customs and traditions } \\
\hline 1 & 4 & The community recognizes the importance of tourism in the national economy. & 7.71 & 5.79 & High \\
\hline 2 & 7 & I think that the practices of tourists are not an obstacle to attracting tourists. & 7.67 & 5.77 & High \\
\hline 3 & 5 & I think tourism does not affect the traditions inherited society. & 7.07 & 5.55 & High \\
\hline 4 & 3 & The community around the tourist areas helping to attract tourists & 6.73 & 5.41 & High \\
\hline 5 & 8 & Residents are not afraid that tourism is helping spread disease. & 6.73 & 5.41 & High \\
\hline 6 & 6 & I think the population is not afraid from the customs and ideas come with tourists. & 6.44 & 5.30 & High \\
\hline 7 & 9 & People are not afraid that tourism affects the ethics of community. & 6.44 & 5.30 & High \\
\hline 8 & 2 & The people in tourist areas show a feeling of friendliness with visitors & 5.47 & 4.92 & High \\
\hline 9 & 1 & The community has a positive attitude toward tourism. & 4.87 & 4.68 & High \\
\hline \multicolumn{3}{|c|}{ The Sub- Field as a whole } & 6.57 & 5.35 & High \\
\hline \multicolumn{6}{|c|}{ Sub-Field: Values } \\
\hline 10 & 18 & I think the community shows affection for tourists. & 6.50 & 5.25 & High \\
\hline 11 & 13 & The community deals respectfully with tourists. & 6.14 & 5.19 & High \\
\hline 12 & 17 & The members of the community deal honestly and sincerely with tourists. & 5.38 & 4.88 & High \\
\hline 13 & 12 & The local community encourages women's involvement in tourism work. & 5.04 & 4.75 & High \\
\hline 14 & 10 & I think tourism does not affect the values of community. & 4.99 & 4.73 & High \\
\hline 15 & 11 & The community encourages work in the tourism sector. & 4.65 & 4.59 & High \\
\hline 16 & 16 & Tourism does not conflict with the values of society. & 4.61 & 4.57 & High \\
\hline 17 & 14 & I think the numbers of females work in tourism are appropriate. & 4.38 & 4.48 & High \\
\hline 18 & 15 & $\begin{array}{l}\text { Behavioral patterns by some members of the community are not an obstacle to attracting tour- } \\
\text { ists. }\end{array}$ & 4.33 & 4.45 & High \\
\hline \multicolumn{3}{|r|}{ thol } & 5.09 & 4.76 & High \\
\hline \multicolumn{6}{|c|}{ Sub-Field: Norms } \\
\hline 19 & 21 & I think the appearance of tourists clothing, eating does not affect the society customs. & 8.70 & 6.15 & High \\
\hline 20 & 20 & I think community members welcome the tourist in Jordan. & 8.35 & 6.02 & High \\
\hline 21 & 19 & I think that tourism does not affect the society norms. & 7.68 & 5.77 & High \\
\hline 22 & 24 & The community show good cooperation with tourists in all their needs. & 7.03 & 5.53 & High \\
\hline 23 & 22 & $\begin{array}{l}\text { I think Community members do not object to restaurants and hotels offering forbidden foods } \\
\text { and beverages. }\end{array}$ & 6.31 & 5.25 & High \\
\hline 24 & 23 & I think the tourist's practices do not affect the environment. & 5.25 & 4.84 & High \\
\hline \multicolumn{3}{|c|}{ The sub- Field as a whole } & 7.23 & 5.60 & High \\
\hline \multicolumn{6}{|c|}{ Sub-Field: Religious beliefs } \\
\hline 25 & 29 & I think the community encourages religious tourism. & 6.31 & 5.25 & High \\
\hline 26 & 28 & I think foreign tourists respect the religious beliefs of citizens & 6.31 & 5.25 & High \\
\hline 27 & 25 & I think tourism does not affect the religious beliefs of the community. & 5.28 & 4.84 & High \\
\hline 28 & 26 & I think tourist's behavior does not affect the religious feelings of citizens. & 4.87 & 4.68 & High \\
\hline 29 & 30 & Community ethics do not conflict with tourism & 4.75 & 4.63 & High \\
\hline 30 & 27 & $\begin{array}{l}\text { My opinion, the appearance of tourists in food and clothing does not affect the religious feel- } \\
\text { ings of citizens. }\end{array}$ & 4.58 & 4.56 & High \\
\hline \multicolumn{3}{|c|}{ The Sub- Field as a whole } & 5.35 & 4.87 & High \\
\hline \multicolumn{3}{|c|}{ The Field as a whole } & 6.06 & 5.15 & High \\
\hline
\end{tabular}

The study aimed to understand the role of cultural dimensions of Jordanian society and their relationships with tourism promotion in Jordan, from the point of view of directors and heads of departments in the directorates of tourism in Jordan through answering each of the following study questions:

First: What is the role of customs and traditions of the society and its relationship in tourism promotion in Jordan? To answer this question, the Mean and the Standard Deviations of the responses of the study sample were extracted from the area of Customs and Tradition sub-field as seen in Table 1. Here the means ranged between (7.71) for "the community recognizes the importance of tourism in the national economy", and (4.87) for "the community has a positive attitude toward tourism". The table also shows that, the role of customs and traditions and its relationship with tourism promotion in Jordan was high with an average of 6.57 , which shows that customs and traditions of Jordanian society did not conflict with the promotion and attract tourists.

Second: What is the role of society values and their relationships with tourism promotion in Jordan? to answer this question, the mean and the standard deviations of the responses of the study sample were extracted from Table 1. Here the means ranged between 6.50 for "I think the community show affection for tourists" and 4.33 for "Behavioral patterns by some members of the community are not an obstacle to attracting tourists". The role of values and their relationships with tourism promotion in Jordan was high with an average of 5.09, which shows that the values of Jordanian society were compatible and did not contradict and conflict with the promotion and attract tourists.

Third: What is the role of society norms and its relationship in tourism promotion in Jordan? To answer to this question, the Mean and the Standard Deviations of the responses of the study sample were extracted from Table 1. Similarly, the means ranged between 8.7 for "I think the appearance of tourists 
clothing, eating does not affect the society customs", and 5.25 for "I think the tourist's practices do not affect the environment." The table also shows that, the role of norms and their relationship with tourism promotion in Jordan was high with an average of 7.23, which shows that the norms of Jordanian society were compatible and not incompatible with the promotion and attraction of tourists, and the Jordanian society in general encouraged domestic and foreign tourism because of its usefulness to the state and citizen.

Fourth: What is the role of society religious beliefs and its relationship in tourism promotion in Jordan? To answer this question, the Mean and the Standard Deviations of the responses of the study sample were extracted from the area of religious beliefs sub-field as seen in Table 1 where the arithmetical means ranged between 7.31 for "I think the community encourages religious tourism", and 4.58 for "My opinion, the appearance of tourists in food and clothing does not affect the religious feelings of citizens". The table shows the role of religious beliefs and their relationships with tourism promotion in Jordan. The result shows that the majority of Jordanian society were conservative and encouraged internal and external tourism and, the tourism did not affect religious beliefs.

Table 2

The summary of mean and standard deviation of the questions

\begin{tabular}{lllccc}
\hline Rank & N & Field & $\begin{array}{c}\text { Arithmetic } \\
\text { Mean }\end{array}$ & $\begin{array}{c}\text { Standard Deviation } \\
\text { Assessment } \\
\text { Degree }\end{array}$ \\
\hline 1 & 2 & Norms & 7.23 & 5.60 & High \\
2 & 4 & Customs and traditions & 6.57 & 5.35 & High \\
3 & 1 & Religious beliefs & 5.35 & 4.87 & High \\
4 & 3 & Values & 5.09 & 4.76 & High \\
\hline \multicolumn{2}{l}{ The Field Cultural Dimensions as a whole } & 6.06 & 5.15 & High \\
\hline
\end{tabular}

Table 2 shows that, the sub-field of norms came first with an average of 7.23, while customs and traditions came second in the order with an average of 6.57 followed by the religious beliefs with an average of 5.35 and the values with an average of 5.09. The table also shows that, the degree of Elements of Cultural Dimensions was high with an average of 6.06.

Table 3

The summary of the mean and standard for tourism promotion

\begin{tabular}{|c|c|c|c|c|c|}
\hline Rank & $\begin{array}{c}\text { Paragraph } \\
\text { Number }\end{array}$ & Paragraph & $\begin{array}{c}\text { Arithmetical } \\
\text { Mean }\end{array}$ & $\begin{array}{c}\text { Standard De- } \\
\text { viation }\end{array}$ & $\begin{array}{c}\text { Degree of as- } \\
\text { sessment }\end{array}$ \\
\hline 31 & 33 & The community recognizes the importance of tourism in the national economy. & 7.67 & 5.77 & High \\
\hline 32 & 43 & I think that the practices of tourists are not an obstacle to attracting tourists. & 7.66 & 5.77 & High \\
\hline 33 & 39 & I think tourism does not affect the traditions inherited society. & 7.65 & 5.76 & High \\
\hline 34 & 44 & The community around the tourist areas helping to attract tourists & 7.08 & 5.55 & High \\
\hline 35 & 37 & Residents are not afraid that tourism is helping spread disease. & 7.02 & 5.52 & High \\
\hline 36 & 36 & I think the population is not afraid from the customs and ideas come with tourists. & 7.00 & 5.52 & High \\
\hline 37 & 46 & People are not afraid that tourism affects the ethics of community. & 6.92 & 5.49 & High \\
\hline 38 & 34 & The people in tourist areas show a feeling of friendliness with visitors & 6.72 & 5.41 & High \\
\hline 39 & 32 & The community has a positive attitude toward tourism. & 6.71 & 5.41 & High \\
\hline 40 & 42 & I think the community shows affection for tourists. & 6.40 & 5.29 & High \\
\hline 41 & 40 & The community deals respectfully with tourists. & 6.31 & 5.25 & High \\
\hline 42 & 41 & The members of the community deal honestly and sincerely with tourists. & 6.24 & 5.23 & High \\
\hline 43 & 31 & The local community encourages women's involvement in tourism work. & 6.13 & 5.18 & High \\
\hline 44 & 45 & I think tourism does not affect the values of community. & 6.13 & 5.18 & High \\
\hline 45 & 38 & The community encourages work in the tourism sector. & 4.96 & 4.71 & High \\
\hline 46 & 35 & Tourism does not conflict with the values of society. & 4.07 & 4.34 & High \\
\hline \multicolumn{3}{|c|}{ The Field Tourism Promotion as a whole } & 6.54 & $\mathbf{5 . 3 4}$ & High \\
\hline
\end{tabular}

The Mean and the Standard Deviations of the responses of the study sample were extracted from the area of Tourism Promotion as seen in Table 3. Here the means ranged from 7.67 for "The community recognizes the importance of tourism in the national economy", to 4.07 for "Tourism does not conflict with the values of society". The Table also shows the degree of the Tourism Promotion was high with an average of 6.54. Table 4 shows the range, mean, standard deviation and variance of the study variables according to the respondents, and according to these indicators there is no big dispersion on the responses, which makes the study more accurate and generalizable. Pearson Correlation coefficients were extracted at level of significance $(\alpha=0.05)$ between degree of Elements of Cultural Dimensions and Tourism Promotion in Table 5. 
Table 4

The summary of statistical observations

\begin{tabular}{lccccc}
\hline Variables & $\mathrm{N}$ & Range & Mean & Std. Deviation & Variance \\
\hline Tourism Promotion & 58 & 3.6 & 6.54 & 5.34 & 2.31 \\
Elements of Cultural & & & & 5.35 & 2.31 \\
Customs and traditions & 58 & 2.84 & 6.57 & 4.76 & 2.18 \\
Values & 58 & 2.17 & 5.09 & 5.60 & 2.37 \\
Norms & 58 & 3.45 & 7.23 & 4.87 & 2.20 \\
Religious beliefs & 58 & 1.73 & 5.53 & 5.15 & 2.72 \\
Elements of Cultural as a whole & 58 & 2.14 & 6.06 & & \\
\hline
\end{tabular}

Table 5

The summary of correlations

\begin{tabular}{|c|c|c|c|c|c|c|c|}
\hline Study Variables & & $\begin{array}{l}\text { Tourism Pro- } \\
\text { motion }\end{array}$ & $\begin{array}{l}\text { Customs and } \\
\text { traditions }\end{array}$ & Values & Norms & $\begin{array}{c}\text { Religious } \\
\text { beliefs }\end{array}$ & $\begin{array}{c}\text { Elements of } \\
\text { Cultural Dimensions } \\
\end{array}$ \\
\hline Tourism & Person Correlation* & 1 & 0.961 & 0.947 & 0.983 & 0.973 & 0.971 \\
\hline \multirow{2}{*}{ Promotion } & Sig.(2-tailed)** & & .005 & .009 & .006 & .008 & .007 \\
\hline & $\mathrm{N}$ & 58 & 58 & 58 & 58 & 58 & 58 \\
\hline \multirow{3}{*}{$\begin{array}{l}\text { Customs and } \\
\text { traditions }\end{array}$} & Person Correlation & 0.961 & 1 & 0.942 & 0.955 & 0.942 & 0.971 \\
\hline & Sig.(2-tailed) & .005 & & .002 & .001 & .004 & .002 \\
\hline & $\mathrm{N}$ & 58 & 58 & 58 & 58 & 58 & 58 \\
\hline \multirow[t]{3}{*}{ Values } & Person Correlation & 0.947 & 0.942 & 1 & 0.987 & 0.975 & 0.961 \\
\hline & Sig.(2-tailed) & .009 & .002 & & .003 & .005 & .008 \\
\hline & $\mathrm{N}$ & 58 & 58 & 58 & 58 & 58 & 58 \\
\hline \multirow[t]{3}{*}{ Norms } & Person Correlation & 0.983 & 0.955 & 0.987 & 1 & 0.952 & 0.983 \\
\hline & Sig.(2-tailed) & .006 & .001 & .003 & & .005 & .006 \\
\hline & $\mathrm{N}$ & 58 & 58 & 58 & 58 & 58 & 58 \\
\hline \multirow[t]{3}{*}{ Religious beliefs } & Person Correlation & 0.973 & 0.942 & 0.975 & 0.952 & 1 & 0.968 \\
\hline & Sig.(2-tailed) & .008 & .004 & .005 & .005 & & .009 \\
\hline & $\mathrm{N}$ & 58 & 58 & 58 & 58 & 58 & 58 \\
\hline \multirow{3}{*}{$\begin{array}{l}\text { Elements of } \\
\text { Cultural } \\
\text { Dimensions } \\
\text { as a whole }\end{array}$} & Person Correlation* & 0.971 & 0.971 & 0.961 & 0.983 & 0.968 & 1 \\
\hline & Sig.(2-tailed)** & .007 & .002 & .008 & .006 & .009 & \\
\hline & $\mathrm{N}$ & 58 & 58 & 58 & 58 & 58 & 58 \\
\hline
\end{tabular}

The correlations between the variables of the study are shown in Table 5, yields the following,

1. There is a statistically significant positive relationship between Customs and Traditions, and Tourism Promotion, when the level of significance is five percent and the relationship is positive $96.1 \%$.

2. There is a statistically significant positive relationship between Values and the Tourism Promotion, when the level of significance is one percent.

3. There is a statistically significant positive relationship between Norms and the Tourism Promotion when the level of significance is one percent.

4. There is a statistically significant positive relationship between Religious beliefs and the Tourism Promotion when the level of significance is one percent.

5. There is a statistically significant positive relationship between Elements of Cultural Dimensions as a whole and the Tourism Promotion when the level of significance is one percent.

In summary the adjusted R-Square value is equal to 0.463 , which means the results could describe approximately $46 \%$ of the changes of dependent variable. Moreover, Table 6 shows the results of ANOVA test. As we can observe, the results of F-Value is significant and this validates the model.

\section{Table 6}

The summary of ANOVA test

\begin{tabular}{|c|c|c|c|c|c|}
\hline Model & Sum of squares & df & Mean Squares & $\mathrm{F}$ & Sig. \\
\hline Regression & 18.72 & 30 & 36.72 & 4.455 & $.007^{\mathrm{a}}$ \\
\hline Residual & 10.83 & 16 & 42.77 & & \\
\hline Total & 29.55 & 46 & & & \\
\hline
\end{tabular}


Table 7

The summary of regression analysis

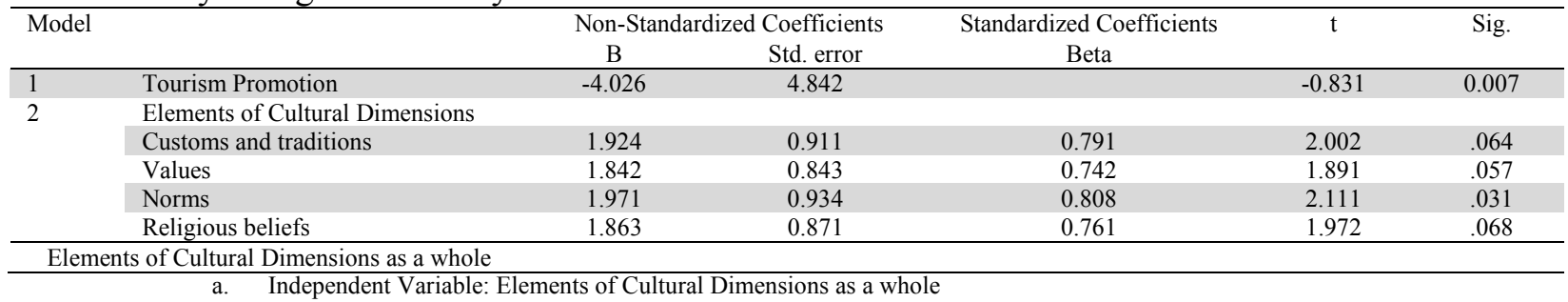

According to Table 7, only the variable Norm is meaningful when the level of significance is five percent and the other variables are not meaningful. The data analysis answers fulfill entire hypothesis developed in the research methodology stage.

The First Hypothesis is:

$H_{O}$ : There is no statistically significant positive relationship of customs and traditions in tourism promotion in Jordan.

$H_{1}$ : There is statistically significant positive relationship of customs and traditions in tourism promotion in Jordan.

The results of the correlation analysis indicate that there was statistically significant positive relationship between customs and traditions in tourism promotion in Jordan, and therefore, the null hypothesis is rejected and the alternative hypothesis is accepted.

The Second Hypothesis is:

$\mathrm{H}_{0}$ : There is no statistically significant positive relationship of values in tourism promotion in Jordan.

$\mathrm{H}_{1}$ : There is statistically significant positive relationship of values in tourism promotion in Jordan.

The results of the correlation analysis indicate that there was statistically significant positive relationship of values in tourism promotion in Jordan, and therefore, the null hypothesis is rejected and the alternative hypothesis is accepted.

The Third Hypothesis is:

$\mathrm{H}_{\mathrm{O}}$ : There is no statistically significant positive relationship of norms in tourism promotion in Jordan.

H1: There is statistically significant positive relationship of norms in tourism promotion in Jordan.

The results of the correlation analysis indicate that there is a statistically significant positive relationship between norms and tourism promotion in Jordan, and therefore, the null hypothesis is rejected and the alternative hypothesis is accepted.

The Fourth Hypothesis is:

$\mathrm{H}_{0}$ : There is no statistically significant positive relationship of religious beliefs in tourism promotion in Jordan.

$\mathrm{H}_{1}$ : There is statistically significant positive relationship of religious beliefs in tourism promotion in Jordan.

The results of the correlation analysis indicate that there was a statistically significant positive relationship between religious beliefs and tourism promotion in Jordan, and, therefore the null hypothesis is rejected and the alternative hypothesis is accepted. The data analysis has shown that in general there is statistically significant positive relationship of cultural dimension (customs and traditions, values, norms, and religious beliefs) in the tourism promotion in Jordan from the point of view of directors and heads of departments in the directorates of tourism in Jordan; and the most strong relationship in tourism promotion in Jordan was society's norms followed by customs, traditions and religious beliefs and society values. 


\section{Conclusions And Recommendations}

In this study, some cultural dimensions, such as customs, traditions, values, norms and religious beliefs, were chosen to determine their relationships with tourism promotion in Jordan. A sample of managers and heads of departments in the tourism directorates in Jordan was selected to know their point of view in this regard. The study and analysis of the results have shown that there was a strong correlation between these dimensions and tourism promotion, in which norms came in the first class, had the most influential compared with all other dimensions. It has been shown that tourism in Jordan did not affect the customs of Jordanian society, and members of the Jordanian community were always welcoming visitors to the tourist areas, and were ready to provide good cooperation with tourists to provide them with all the help. The study also has shown the Jordanians' awareness of the importance of the tourism sector in the national economy, and attracting more visitors. They are not afraid that tourists could have any influence on their customs and traditions, values, morals and ethics, not even their religious beliefs and they always encourage tourism, especially religious tourism. Based on the results, the researcher recommends conducting further studies on other cultural dimensions to determine their impacts on tourism promotion in Jordan and selecting another study society and sample. It also recommends the need to increase the interest in tourism areas in Jordan by governments to attract more visitors, especially with regard to religious and therapeutic tourism, as well as, conduct workshops for the local community surrounding the tourist areas to familiarize them with how to deal with tourists and especially foreigners in accordance with Jordanian customs and traditions.

\section{References}

Blake, J. (2018). Further reflections on community involvement in safeguarding intangible cultural heritage. In Safeguarding Intangible Heritage (pp. 31-49). Routledge.

Blackstock, K. (2005). A critical look at community based tourism. Community Development Journal, 40(1), 39-49.

Belch, G. E., \& Belch, M. A. (2004). Advertising and Promotion: An Integrated Marketing Communications Perspective 6th. New York: NY: McGraw-Hill.

Cole, S. (2006). Cultural tourism, community participation and empowerment. Cultural tourism in a changing world: Politics, participation and (re) presentation, 89-103.

Dibb, S., \& Simkin, L. (1997). A program for implementing market segmentation. Journal of Business \& Industrial Marketing, 12(1), 51-65.

Dragouni, M., \& Fouseki, K. (2018). Drivers of community participation in heritage tourism planning: an empirical investigation. Journal of Heritage Tourism, 13(3), 237-256.

Goodwin, H. (2002). Local community involvement in tourism around national parks: opportunities and constraints. Current Issues in Tourism, 5(3-4), 338-360.

Kotler, P., Armstrong, G., Saunders, J., Wong, V., Miquel, S., Bigné, J. E., \& Cámara, D. (2000). Introducción al marketing. Segunda edición europea. Precinte Hall.

McCarthy, J. E., \& Perreault, W. D. (1993). Basic Marketing: a global managerial approach, ed. Boston. Ministry of Tourism, Annual Report (2018), Jordan.

Simpson, K. (2001). Strategic planning and community involvement as contributors to sustainable tourism development. Current Issues in Tourism, 4(1), 3-41.

Simpson, M. C. (2008). Community benefit tourism initiatives-A conceptual oxymoron?. Tourism Management, 29(1), 1-18.

Ying, T., \& Zhou, Y. (2007). Community, governments and external capitals in China's rural cultural tourism: A comparative study of two adjacent villages. Tourism Management, 28(1), 96-107.

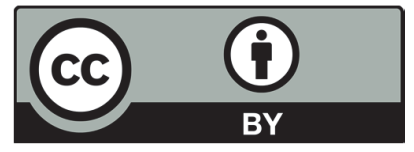

(C) 2019 by the authors; licensee Growing Science, Canada. This is an open access article distributed under the terms and conditions of the Creative Commons Attribution (CCBY) license (http://creativecommons.org/licenses/by/4.0/). 